\title{
Public Perception towards the Election Commission in Malaysia
}

\author{
Muhammad Fathi Yusof ${ }^{1}$, Mohd Al'Ikhsan Ghazali ${ }^{1}$, Nurhidayu Rosli ${ }^{1} \&$ Muhammad Sakirin Alias ${ }^{1}$ \\ ${ }^{1}$ UTM Razak School, University of Technology, Malaysia \\ Correspondence: Muhammad Fathi Yusof, UTM Razak School, University of Technology,Malaysia, Campus of \\ Kuala Lumpur, Jalan Sultan Yahya Petra, 54100, Kuala Lumpur, Malaysia. Tel: 60-32-615-4634. E-mail: \\ fathi.kl@utm.my/fathiyusof@gmail.com
}

Received: July 3, 2015 Accepted: September 2, 2015 Online Published: October 21, 2015

doi:10.5539/ass.v11n26p347 URL: http://dx.doi.org/10.5539/ass.v11n26p347

\begin{abstract}
This study analyzed the public perception towards the Election Commission (EC) in Malaysia using quantitative analysis in order to evaluate the conduct of the EC in terms of free and fair conduct. The population of this study involved a total of 1104 registered voters. Using Statistical Package for the Social Science (SPSS) to analyze the data, the study arrived at certain pattern of results. An instrument namely; questionnaire was utilised in gathering the data needed. Likert scale was employed in the questionnaires in order to classify the public perception. The study found out that the public perception towards the EC in Malaysia vary according to the qualities that the EC should hold; independency (strong leadership), impartiality, professionalism and integrity, and transparency and accountability. The study concluded that it is important for the EC in Malaysia to improve on certain aspects in practice that effect public perception towards the qualities of the EC because it is the pivotal role of the EC to conduct free and fair electoral process in the country for the benefit of the country and the people.
\end{abstract}

Keywords: election commission, election in Malaysia, public perception, quantitative analysis

\section{Introduction}

Election is an essential element in a democratic country like Malaysia. Democracy has been practiced since 1955 when Malaysia was on its way to regain independence. The electoral framework under 1955 general election and the earlier elections have been strengthened with the constitutional structure. The Reid Commission had proposed four important elements of election in the new Constitution namely, the functions and organization of the Election Commission (EC), the delimitation of constituencies, election petitions and the right to vote (Fathi, 2013). The EC is responsible to prepare and maintain the electoral rolls, determine the boundaries of constituencies, and to conduct elections on every level. Thus, we regard it as a matter of great importance that this Commission should be completely independent and impartial. We therefore recommend that the EC should be a permanent body that its members should be persons in whom all democratic parties and all communities have complete confidence (Note 1).

Meanwhile, the right to vote goes to the public subject under constitutional framework. So, it will be the main purpose of this study to investigate the public perception towards the EC in Malaysia. Specifically, we investigated the aspects of free and fair conduct of the EC from the public point of view. The survey was conducted in June 2014 and finished by March 2015. 1104 respondents among voters participated in answering the questionnaires. Upon receiving all answered questionnaires, the data were analyzed using Statistical Package for the Social Sciences (SPSS). A questionnaire with 7 questions concerning justice and freedom in EC's treatment to political parties, leadership practiced, the implimentation of electoral delineation process, attitude while working and distribution of voting districts, had been distributed.

\section{Problem Statement}

Free and fair in the conduct of an election management body significantly determine the public perception on the realibility of the EC. Based on the concept of free and fair conduct, the EC must ensure that all electoral laws and procedures are accurately and meticulously implemented. Moreover, the election procedures must be precise, clear and consistent. This is because in any competitive election, the laws and procedures play an important role as 'the rules of the game' among the contesting political parties, therefore any changes to them, without adequate notice and by illegal way would unfairly affect their chance to win the election (Muhammad Fathi, 2013). However, as was the case during the general election in 2013, an issue regarding the indelible ink used in voting 
process has been raised by the public along with the transparency issue in the counting process. The EC's creadibility and integrity are in question. The institution that manages the electoral process must be credible, independent and perceived as completely fair by the public as well as by the political parties and election candidates (Fathi, 2013).

There have been many other cases including the allegations of power abuse and money politics including the infamous 'you help me, I help you' remark made by the Prime Minister Datuk Seri Najib Abdul Razak during the Sibu by-election in 2010. However, the EC repeatedly declined to take a clear stand, arguing that corruption is out of its purview and it should be determined by other government agencies (Election Management Report, 2013). Thus, by studying the data, we are able to analyze the perception made by the public towards the EC as a respond to all the issues mentioned above.

Therefore, it would be the major objective of this study to examine the public perception towards the EC to find out whether the EC is successful in conducting a free and fair election. The questions were designed based on the following discussion in the literature review below. There are certain qualities that the EC should possess in order to be seen as free and fair.

\section{Literature Review}

In a functioning democracy, an institution that manages the electoral process must be credible, independent and perceived as completely fair by the public. A competent and neutral electoral management body is essential as it plays the central role in free and fair elections. So far, there are works by Goodwin-Gill, Boda, Elklit and Reynolds who provide a significant reference for the study of quality of elections at local level. The combination of several methodologies in judging elections as well as the theoretical study on the link between democracy and election provides a useful guide for evaluative research on electoral system in Malaysia. Another study regarding the election management body is by Wall and International Institute for Democracy and Electoral Assistance (2006) who provides international perspective on electorate standards as the foundation for research on electoral process in Malaysia. But it is insufficient to understand the question of free and fair practice of the EC in Malaysia. For that reason, a study on free and fair conduct of the EC in Malaysia requires a thorough examination not only on the international law and principles, but from the public perspective as well.

Meanwhile, there are works on the quality of elections in Malaysia which focus on specific area of electoral process or on specific general elections. In this group, there are two types of documents i.e.: academic works on democratic elections and reports of election observers on general elections or by-elections. There are a few recent works which give some account on specific elements such as the works by Horowitz (2005) and Kessler (2005) who focus on the electoral system. There are also researches on the electoral rolls (Ong, 2005), the role of the Election Commission (Lim, 2005), and the electoral delimitation (Lim, 2003; Ong \& Welsh, 2005). On the other hand, there are also a number of reports on electoral observation missions. Since the electoral observation activities in Malaysia is very limited, there are only two significant reports on general elections i.e. the report of Election Watch consist of six Malaysian prominent figures led by the former Lord President Tun Suffian Hashim and the report of the Commonwealth Election Observation-both reports were made based on the conduct of 1990 General Elections. These works are helpful in understanding the conduct of election and to assess certain aspect of the electoral process, but they do not offer sufficient analysis on the works of the EC in the current political landscape. Besides that, the works only come from the researchers' or observers' observations while this research investigates the public perception towards the EC.

The only close work related to free and fair conduct of the EC is a work by Muhammad Fathi (2013). Based on systematic scholarly work on free and fair elections in Malaysia using the constitutional and legal settings, the research showed a credible EC should has certain basic qualities such as independency, impartiality, transparency and accountability as vital prerequisite for free and fair elections. In order to create a good perception among the public, the EC must conduct the election professionally and efficiently, with adequate funds and independent human resources. However, the work focuses more on constitutional and legal settings instead of the public perception. Therefore, given the nature and scope of the available literature, this study seeks to fill the gap and study the free and fair conduct of the EC by looking at the public perception towards the EC. The qualities observed are independence, impartiality, transparency and accountability, professionalism and integrity of the EC.

\section{Methodology}

The research design for this study is quantitative method specifically survey-based in order to find the data needed. The population of this study is the ensemble of eligible registered voters in the country. This study used an instrument namely; questionnaire. The questionnaires instrument is divided into two sections: the 
demographic and psychographic section. The demographic section is used to gather information about the biodata of the respondents while the psychographic section focused on the research questions. The questionnaire is drafted in short sentences consisting of 7 questions. It used close and open ended techniques in order to give the respondents enough room to fill in responses to the questions.

The questionnaires were distributed among 1104 public respondents. This instrument was ministered by several researchers. The researchers and research assistants were given four weeks to collect and return the filled instrument. As for the respondents, they were given 15 minutes to answer the questionnaire. In order to ensure the reliability of the study instrument, a pilot test was conducted among the college students to ascertain the reliability of the research instrument (questionnaire). 15 respondents were chosen to perform this purpose.

\section{Data Presentation and Analysis}

Below are the data generated using quantitative data analysis-SPSS. Data analysis is presented in tables and charts. The tables below provide the demography of respondents in the cause of this study.

Table 1. Sex of respondents

\begin{tabular}{ccc}
\hline & Frequency & Percentage (\%) \\
\hline Male & 501 & 45.4 \\
Female & 603 & 54.6 \\
\hline Total & 1104 & 100 \\
\hline
\end{tabular}

Table 1 above described the sex of respondents. From the table, $501(45.4 \%)$ respondents are male while $603(54.6 \%)$ respondents are female. This result shows that there are more female than male in the sample studied.

Table 2. Age of respondents

\begin{tabular}{ccc}
\hline & Frequency & Percentage $(\%)$ \\
\hline $20-24$ & 568 & 51.4 \\
$25-29$ & 220 & 19.9 \\
$30-35$ & 114 & 10.3 \\
$40-50$ & 95 & 8.6 \\
$51-60$ & 62 & 5.6 \\
Over 60 years & 45 & 4.1 \\
\hline Total & 1104 & 100 \\
\hline
\end{tabular}

From the table above, half of the respondents, 568 (51.4\%) fall within 20-24 years. Whereas, the rest fall within 25-29 years, 220 (19.9\%), 30-35 years, 114(10.3\%), $40-50$ years, $95(8.6 \%), 51-60$ years, $62(5.6 \%)$, and over 60 years, $45(4.1 \%)$. The number of respondents decreased as the age grow. According to the statistic, it means majority of the respondents are within the prime age of participating in election as voters.

Table 3. Ethnicity of respondents

\begin{tabular}{ccc}
\hline & Frequency & Percentage $(\%)$ \\
\hline Malay & 940 & 85.1 \\
Chinese & 95 & 8.6 \\
Indian & 41 & 3.7 \\
Others & 28 & 2.5 \\
\hline Total & 1104 & 100 \\
\hline
\end{tabular}

In the table above, 940 (85.1\%) from the total respondents are Malay. Only $95(8.6 \%)$ are Chinese, $41(2.5 \%)$ are Indian while other ethnics are $28(2.5 \%)$. This means, majority of the respondents are among the Malay voters in Malaysia. 


\subsection{Research Question 1: The EC Gives Equal Treatment to All Political Parties in Malaysia}

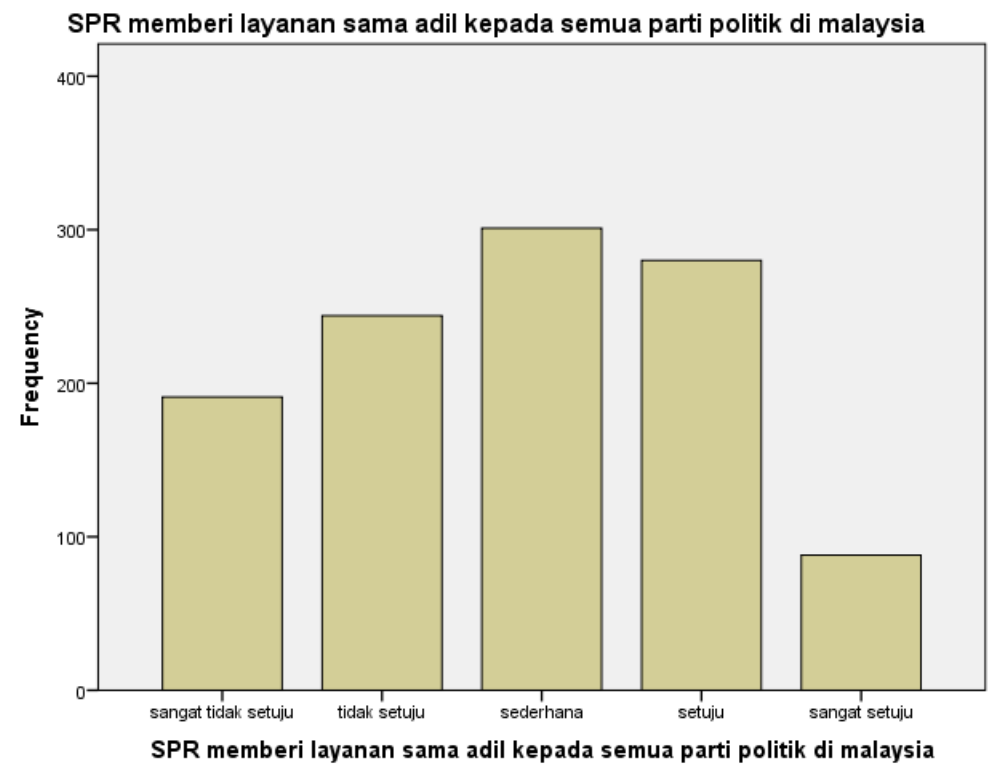

Figure 1. Respondents view on whether the EC gives equal treatment to all political parties in Malaysia

From Figure 1, $280(25.4 \%)$ respondents agree that the EC gives equal treatment to all political parties in Malaysia along with only $88(8.0 \%)$ strongly agree with the statement. However, $301(27.3 \%)$ of respondents have the average opinion regarding the statement whereas $244(22.1 \%)$ and $191(17.3 \%)$ respondents disagree and strongly disagree that the EC gave equal treatment to all political parties in Malaysia.

The result shows that majority of the public disagree that the EC gives equal treatment to all political parties in Malaysia. Only a small percentage of the public see the EC as being equal to all political parties in Malaysia.

\subsection{Research Question 2: I Am Convinced That the EC Leadership Is Free and Fair}

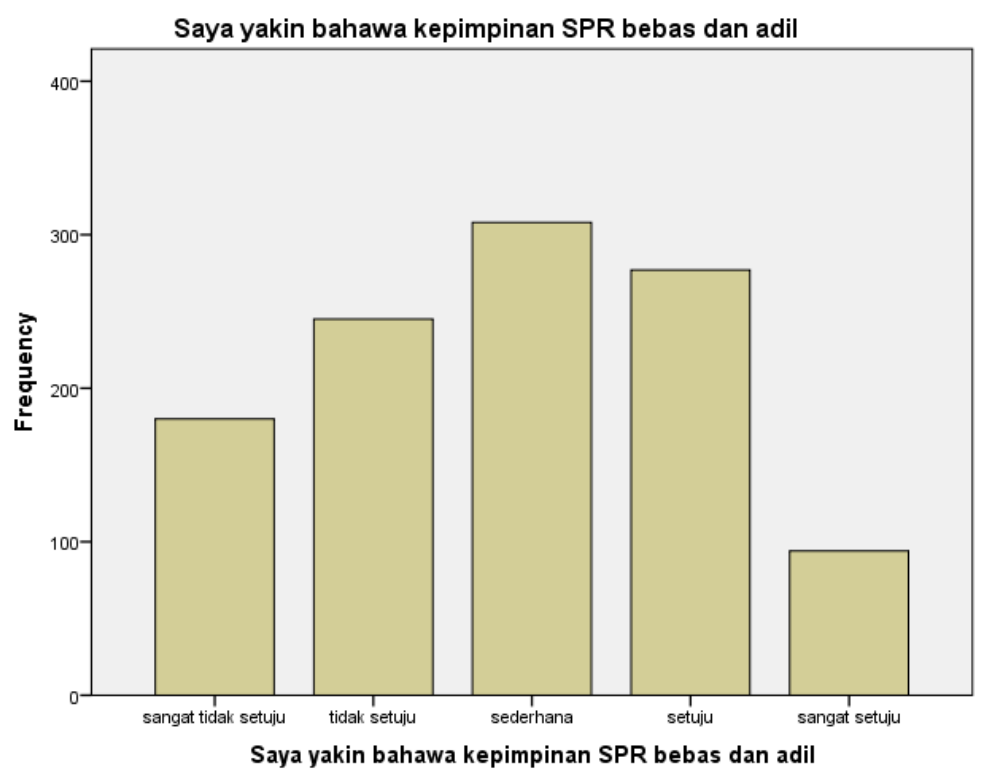

Figure 2. Respondents view on whether they convinced that the EC leadership is free and fair

From Figure 2, 94 (8.5\%) respondents strongly agree while 277 (25.1\%) respondents agree that they convinced the EC leadership is free and fair. Meanwhile, $308(27.9 \%)$ respondents are average in their view whereas 180 $(16.3 \%)$ respondents along with $245(22.2 \%)$ respondents strongly disagree and disagree on the statement above. 
Since majority of the respondents are of the opinion that they convinced the EC leadership is free and fair is low, it therefore means that the public perceived the EC leadership in Malaysia as not free and fair.

\subsection{Research Question 3: The Process of Electoral Delineation Is Fair, Transparent and Equal}

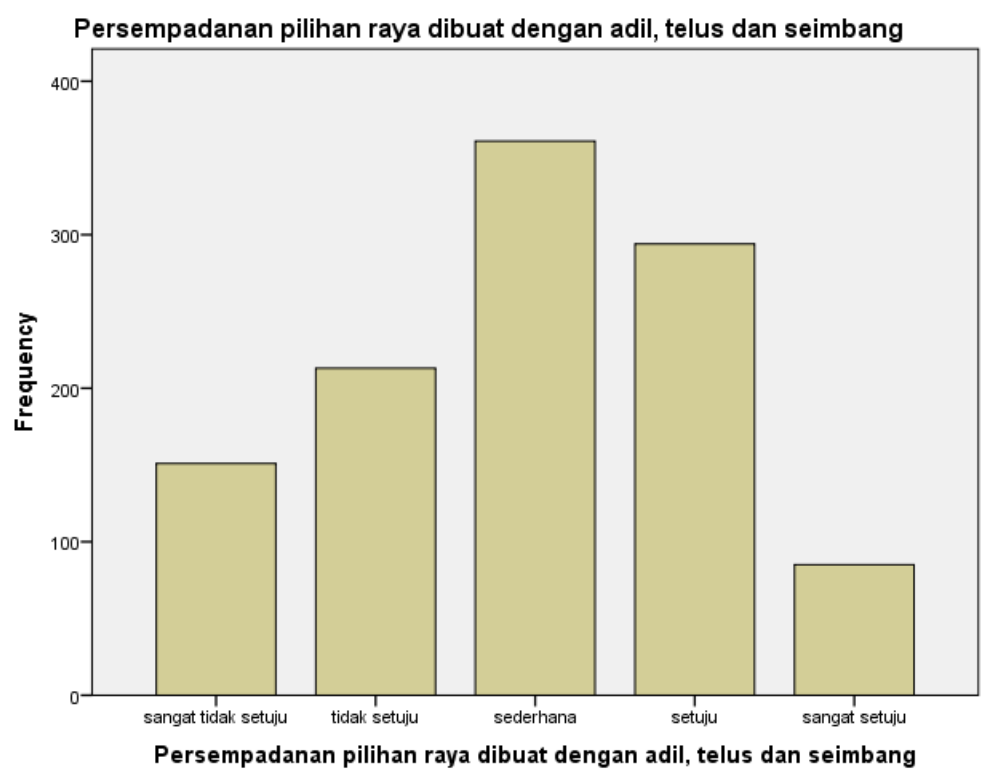

Figure 3. Respondents view on the process of electoral delineation is fair, transparent and equal

Figure 3 analyses the opinion of respondents on whether the process of electoral delineation is fair, transparent and equal. From the figure, $361(32.7 \%)$ of respondents chose to have average view. Only $85(7.7 \%)$ of respondents strongly agree with the statement while $294(26.6 \%)$ respondents agree that the process of electoral delineation is fair, transparent and equal. However, 151 (13.7\%) strongly disagree whereas 213 (19.35) disagree with the statement.

Thus, the analysis shows that majority of the public perceived the process of electoral delineation is fair, transparent and equal with very low percentage of the respondents who disagree with the statement.

\subsection{Research Question 4: I Am Convinced That the Election Officer Is Free and Fair}

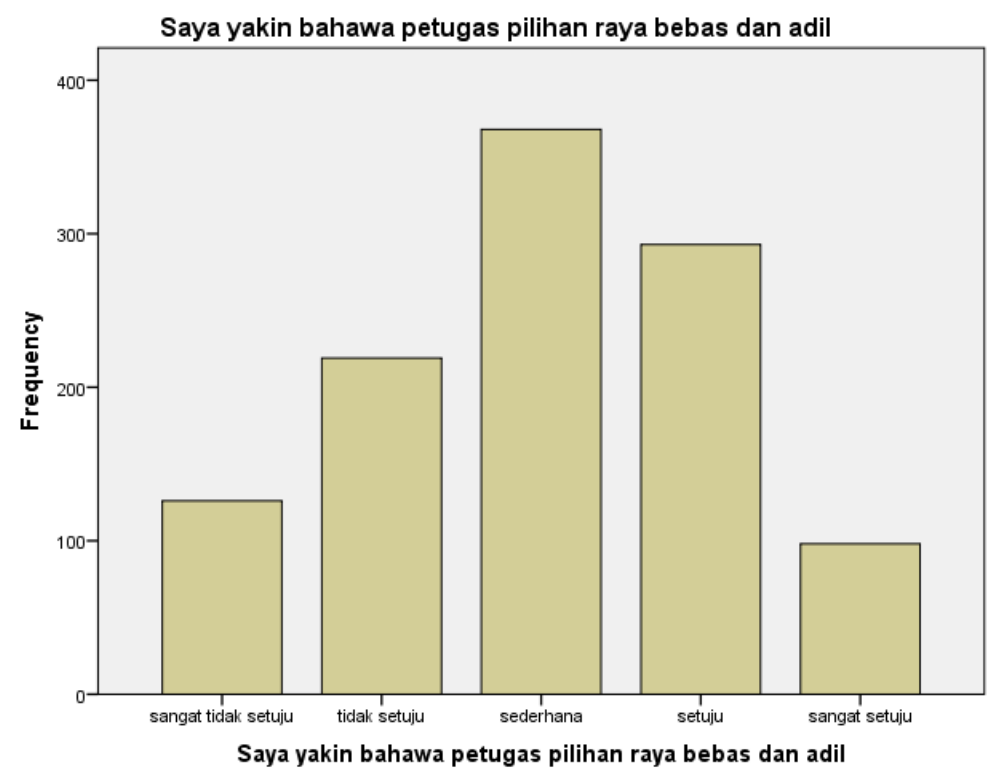

Figure 4. Respondents view on whether they convinced that the election officer is free and fair 
The fourth research question analyses whether the respondents convinced that the election officer is free and fair. According to Figure 4, 98 (8.9\%) respondents strongly agree while 293(26.5\%) agree that they convinced the election officer is free and fair. However, $126(11.4 \%)$ and $219(19.8 \%)$ of respondents strongly disagree and disagree that the election officer is free and fair. Meanwhile, 368 (33.3\%) of respondents chose to be average with their view.

Therefore, it can be said from the analysis that majority of the public see the election officer as free and fair. However, although only small percentage of respondents disagree with the view, the percentage of strongly disagree is much higher than respondents who strongly agree.

5.5 Research Question 5: The EC Is Successful in Ensuring Total Distribution of Voters in Each Areas Is Relevant and Fair

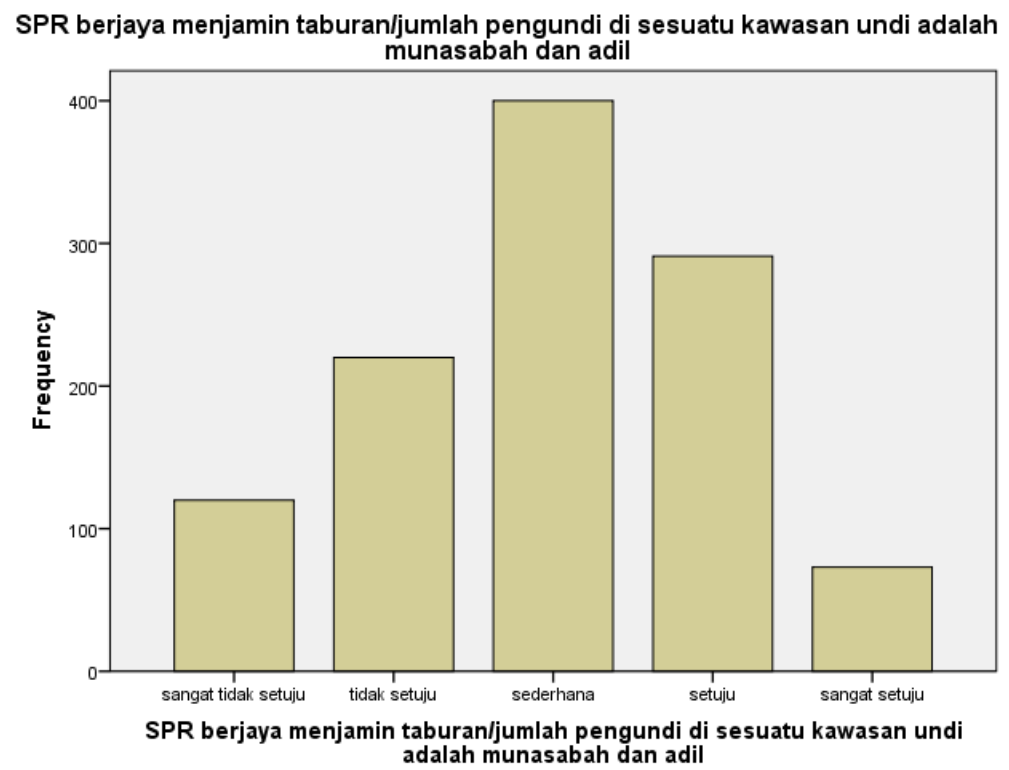

Figure 5. Respondents view on the EC is successful in ensuring total distribution of voters in each areas is relevant and fair

Figure 5 looks at respondents view on the EC successfulness in ensuring total distribution of voters in each areas is relevant and fair. From Figure 5, only $73(6.6 \%)$ of respondents strongly agree that the EC is successful in ensuring total distribution of voters in each areas is relevant and fair. At the same time, 291 (26.4\%) of respondents also agree with the statement. Meanwhile, $120(10.9 \%)$ chose to strongly disagree and do not view the EC as successful in ensuring total distribution of voters in each areas is relevant and fair with another 220 (19.9\%) also disagree. The remainder of 400 (36.2\%) respondents remain average.

The analysis indicates that among those who viewed the EC as successful in ensuring total distribution of voters in each areas is relevant and fair, majority opined that the EC successfulness is just average. 


\subsection{Research Question 6: The EC Has Carried Out Their Duties in Transparency and Accountability}

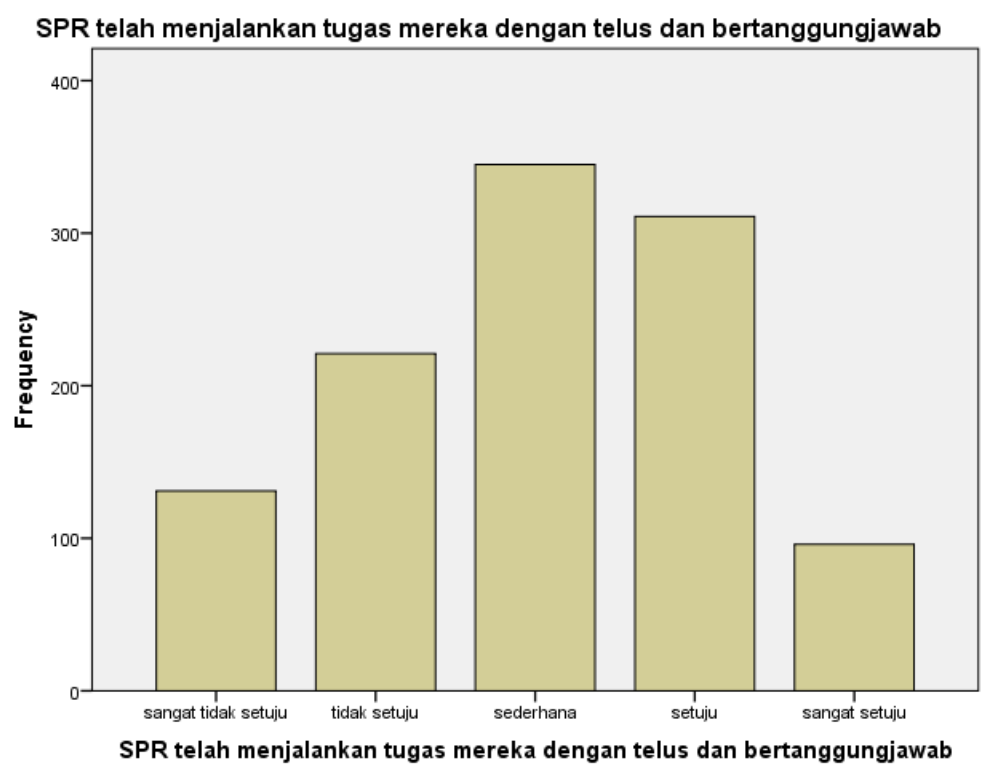

Figure 6. Respondents view on the EC has carried out their duties in transparency and accountability

Figure 6 looks at respondents view on the EC carrying out their duties in transparency and accountability. The figure indicated that $96(8.7 \%)$ along with $311(28.2 \%)$ of respondents strongly agree and agree that the EC has carried out their duties in transparency and accountability. While the other $345(31.3 \%)$ of respondents chose to be average with their view, another $131(11.9 \%)$ and $221(20.0 \%)$ of respondents strongly disagree and disagree that the EC has carried out their duties in transparency and accountability.

The result from Figure 6 shows that majority opted to view the EC as carrying out their duties in transparency and accountability. However, there is still respondents who view the EC performance as average and the percentage is the highest among all scales if view separately.

5.7 Research Question 7: The EC Has Abided by the Rules and Regulations in the Elections

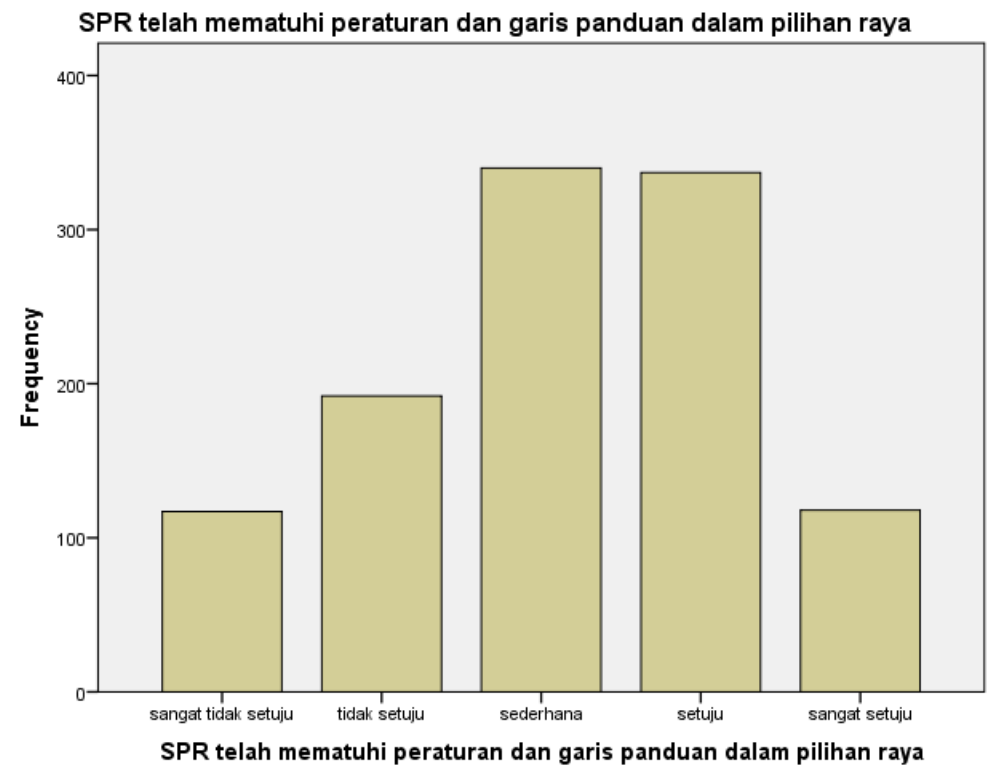

Figure 7. Respondents view on the $\mathrm{EC}$ has abided by the rules and regulations in the elections

The last research question analysed the respondents view on how far they view the EC has abided by the rules 
and regulations in the elections. The result in the chart above finds that $118(10.7 \%)$ and $337(30.5 \%)$ of respondents strongly agree and agree that the EC has abided by the rules and regulations in the elections whereas $117(10.6 \%)$ and $192(17.4 \%)$ of respondents strongly disagree and disagree with the statement. The remainder of $340(30.8 \%)$ remains average with their view.

A big majority of the respondents chose to agree that the $\mathrm{EC}$ has abided by the rules and regulations in elections. Thus, it can be said that the public perceived the EC has abided by the rules and regulations in the elections in Malaysia.

\section{Discussion of Findings}

In analysing the data collected, the study showed that there is higher percentage of women than men in the sample studied. It also revealed that most of the people sampled are majoritily from Malay ethnic and falls within 20-24 years of age, which means that they are active citizens participating in the country political process. From the result of the analysis above, we could evaluate the public perception towards the EC from the specific qualities that the EC should possess as discussed in the problem statement; independency, impartiality, transparency and accountability, professionalism and integrity by classifying the questions into the related qualities.

Table 4. The classification of qualities of the EC by questions

\begin{tabular}{lc}
\hline Question & Quality \\
\hline Research Question 1: & Impartiality \\
The EC gives equal treatment to all political parties in Malaysia & Independence (strong \\
Research Question 2: & leadership) \\
I am convinced that the EC leadership is free and fair & Impartiality \\
Research Question 3: & Professionalism and integrity \\
The process of electoral delineation is fair, transparent and equal & Impartiality \\
Research Question 4: & \\
I am convinced that the election officer is free and fair & Transparency and accountability \\
Research Question 5: & \\
The EC is successful in ensuring total distribution of voters in each areas is relevant and & \\
fair & Professionalism and integrity \\
Research Question 6: & \\
The EC has carried out their duties in transparency and accountability & \\
Research Question 7: & \\
The EC has abided by the rules and regulations in the elections &
\end{tabular}

\subsection{Independence (Strong Leadership)}

The analysis from the quantitative approach reveals that majority of the public disagree that the EC gives equal treatment to all political parties in Malaysia. Only small percentage see the EC as being equal to all political parties in Malaysia. This is evident from the fact that only $88(8.0 \%)$ of respondents strongly agree and 280 (25.4\%) agree, while 435 (39.4\%) disagree with the statement that the EC gives equal treatment to all political parties in Malaysia.

From the result above, it can be concluded that majority of the public are not convince with the EC leadership. It shows the EC is not perceived as being an independent body which should be the vital quality of a strong leadership in an election management body in order to conduct free and fair election in Malaysia. It is important to have the commitment to neutrality and the culture of independence among members of the EC and officers. A credible and dedicated leadership will build the public confidence in the conduct of election. The factors that influence the existence of these normative qualities are the mode of appointments of its members and officers, the security of tenure, their background, and personal integrity (Fathi, 2013). For example, the appointment of former civil servants as election commissioners is another main factor behind the EC's conservativeness as they were used to act under government's instructions (Kuek Ser, 2011).

\subsection{Impartiality}

The study revealed that the public perceived the EC leadership in Malaysia as not free and fair since majority of the respondents are not convinced that the EC leadership is free and fair. Total respondents who disagree is 425 
(38.5\%) compared with only 371 (33.61\%) respondents who agree and $308(27.9 \%)$ who chose to be average with their view. However, the analysis then shows majority of the public perceived the process of electoral delineation is fair, transparent and equal with low percentage of the respondents who disagree with the statement. In the meantime, the analysis also indicates that among those who viewed the EC as successful in ensuring total distribution of voters in each areas is relevant and fair, majority opined that the EC successfulness is just average.

By the different results reveal, the public perceived the EC as having a tendency towards split opinion, hence showing that impartiality is not clear. However, in the aspects of carrying out the process of electoral delineation and distributing voters, the public trusted the EC as being transparent. There were cases prior to Bersih 2.0, the deputy of election commissioner, Wan Omar Wan Ahmad called the co-chairperson of Bersih 2.0, S.Ambiga as the 'Destroyer of democracy' and said the EC will not deal with Bersih 2.0 in matters related to electoral reform aside from calling the opposition leader, Datuk Seri Anwar Ibrahim as 'King of slander' over Anwar allegation that 500000 early ballots from security force personnel had been tampered with (Election Management Report, 2013).

Nevertheless, the EC is required to treat all election participants equally, fairly and evenhandedly, without giving advantage to any political tendency or interest group. The complete impartiality of the EC is an essential element of the commission as proposed by the Reid Commission. However, since the impartiality is a state of mind more than a statement in law, the practical aspect of the impartiality of Commission significantly depends on the EC's behaviour and attitudes to its stakeholders.

\subsection{Transparency and Accountability}

The result from the chart above shows that majority opted to view the EC as carrying out their duties in transparency and accountability. However, there is still respondents who viewed the EC performance as average and the percentage is the highest with $31.3 \%$ among other scales if viewed every scales separately. Nevertheless, it can be concluded that the public still finds the EC as having the transparency and accountability qualities. Even the Merdeka Center as an independent election watch body find the EC as failed in being transparency with its conduct of election. According to the Merdeka Center (2013);

In the case of advance voting, the EC had said that the party agent are allowed to stay overnight in the police lock up which was used to keep the ballot boxes of advance voting provided that they abide to the police lock up rules. However, we have noticed that the party agents were not allowed to stay in the police lock up to watch over the ballot boxes. This has raised doubt whether the ballot papers were being tampered with, as the advance voting were carried out five days before the polling day. The counting of the advance voting ballots only began on 4 pm on May 5 .

Above is few cases involving the conduct of the EC in terms of transparency. As the most important body to conduct democratic elections, the EC must be independent and impartial. Hence, to achieve this, the EC must have a high standard of transparency and accountability. Transparency suggests that the EC must discloses all material facts that underlying its important decisions such as choice of election date, enforcement of certain regulation, rejection and acceptance of nomination forms in disputes, and decisions or actions such as redistribution of voters particularly postal voters and change of status of voters that requires comprehensive explanations from the EC. Besides that, transparency also covers the aspect of integrity in voting, counting and tabulation processes. The failure of the EC to exercise transparency would lead to public assumption that it has made decisions impartially to favour certain political party.

Undoubtedly the transparency and accountability are important features of a credible and fair EC to ensure that the election management carry out their duties in accordance to the concept of free and fair election.

\subsection{Professionalism and Integrity}

The analysis then reveals that majority of the public perceived the election officer as free and fair. However, although only small percentage of respondents disagree with the view, the percentage of strongly disagree is much higher than respondents who strongly agree, that is $126(11.4 \%)$ compared with only $98(8.9 \%)$ of respondents. Meanwile, a big majority of the respondents chose to agree that the EC has abided by the rules and regulations in elections. Thus, it can be said that the public perceived the EC has abided by the rules and regulations in every elections held in Malaysia.

Therefore, in terms of integrity and professionalism, the public viewed the EC as having those qualities and perceived them as following the rules and regulations in managing the election despite all the issues raised by the opposition parties. For example, in the 2014 general elections, the EC had suddenly announced two hours 
extension of the voting period to 7:00 for all polling centres in Selangor. This extension was contrary to the authorized voting time as stipulated in the Notice of Contested Election which was published in the Gazette (Fathi, 2013). Based on the concept of professionalism, the EC must ensure that all electoral laws and procedures are accurately and meticulously implemented. Moreover, the election procedures must be precised, clear and consistent. This is because in any competitive election, the laws and procedures play an important role as 'the rules of the game' among the contesting political parties, therefore any changes to them, without adequate notice and by illegal way would unfairly affect their chance to win the election.

Hence, the professionalism and integrity of the EC is a pre-requisite for a free and fair election. Non-compliance with the election procedure and directive, although in some cases not nullify the election, is a serious fault and discrimination. Inconsistency of the EC in issuing directives and in implimenting election procedures had caused unnecessary confusion among voters and political parties significantly eroded the public confidence. In most cases the victim is the opposition, since the ruling party has advantage of having direct access with the EC-making process.

\section{Conclusions}

In summary, we have quantitatively verified that, public perception towards the EC tend to vary according to specific qualities of the EC in terms of strong leadership (independent), impartiality, professionalism and integrity, and transparency and accountability. However, the public still perceived the EC as a trusted election management body although there are still few disputed issues on the free and fair conduct of the EC during the elections. Nevertheless, there are need to reform the laws on the election management body to reduce the partial involvement of the government and ruling party in the affairs. The EC also deserves a wider autonomy in its legislative authority, financial allocation, human resource system, and so on, so that it can have more freedom to conduct free and fair elections. As a conclusion, in line with the findings in this study, it is important for the EC in Malaysia to improve on certain aspects that effect public perception towards the EC during elections because it is the pivotal role of the $\mathrm{EC}$ to conduct free and fair electoral process in the country for the benefit of the country and the public.

\section{References}

Boda, M. D. (2005). Judging elections by public international law: A tentative framework. In M. D. Boda (Ed.), Revisiting free and fair elections. Geneva: Inter-Parliamentary Union. http://dx.doi.org/10.1080/00344 890508523312

Elklit, J. (1938). Electoral institutional change and democratisation. Democracy and Political Change in the "Third World", 55-74. http://dx.doi.org/10.4324/9780203402405_chapter_4

Horowitz, D. L. (2005). Political goals and first-past-the-post. In M. Puthucheary, \& N. Othman (Eds). Elections and democracy in Malaysia (pp. 385-400). Bangi: PenerbitUKM.

Kessler, C. S. (2005). A proposal for a preferential voting system. In M. Puthucheary, \& N. Othman (Eds.), Elections and democracy in Malaysia (pp. 404-422). Bangi: Penerbit UKM.

Kuek Ser, K. K. (2011, July 29). No way we can go against the system, says EC. Malaysiakini. p. A4.

Hai, L. H. (2003). The delineation of peninsular electoral constituencies: Amplifying Malay and UMNO power. In F. L. K. Wah, \& J. Saravanamuttu (Eds.), New politics in Malaysia (p. 25). Singapore: Institute of Southeast Asia Studies.

Hai, L. H. (2005). Making the system work: The election commission. In M. Puthucheary, \& N. Othman (Eds.), Elections and democracy in Malaysia (pp. 249-290). Bangi: Penerbit UKM.

Election Watch. (2013). Journal of Democracy, 24(3), 178-182. http://dx.doi.org/10.1353/jod.2013.0044

Yusof, M. F. (2013). The constitutional and legal frameworks for free and fair election in Malaysia (Unpublished doctoral dissertation). University of Tecnology, Malaysia, Malaysia.

Ming, O. K. (2005). Examining the electoral rolls. In M. Puthucheary, \& N. Othman (Eds.), Elections and democracy in Malaysia (pp. 292-314). Bangi: Penerbit UKM.

Ming, O. K., \& Welsh, B. (2005). Electoral delimitation: a case study of Kedah. In M. Puthucheary, \& N. Othman (Eds.), Elections and democracy in Malaysia (pp. 316-344). Bangi: Penerbit UKM.

Reynold, A., \& Ors. (2005). Electoral system design: The new international IDEA handbook. Sweden: International Institute for Democracy and Electoral Assistance (IDEA). http://dx.doi.org/10.5860/choice. $45-4011$ 
Wall, A., \& International Institute for Democracy and Electoral Assistance. (2006). Electoral management design: The International IDEA handbook. Stockholm: International IDEA.

\section{Notes}

Note 1. Para 71 of the Reid Commission Report.

Note 2. See Regulation 11(5)(d) and Form 8 (First Schedule) of the Election (Conduct of Elections) Regulation 1981. In 2006, this provision was amended by substituting for the words 'cause to be published in the Gazette and also in such manner as he thinks fit a notice' the words 'give, in such manner as he thinks fit, a notice to the public' Section 3 of the Elections (Conduct of Elections) (Amendment) Regulations 2006 (P.U.(A) 164.)

\section{Copyrights}

Copyright for this article is retained by the author (s), with first publication rights granted to the journal.

This is an open-access article distributed under the terms and conditions of the Creative Commons Attribution license (http://creativecommons.org/licenses/by/3.0/). 